Mirostawa Hanusiewicz-Lavallee (Lublin)

\title{
Okrucieństwo kacyrskie przeciw katolikom w Anglijej, czyli polski głos w sporze o męczeństwo
}

Dziełko Okrucieństwo kacyrskie przeciw katolikom w Anglijej, krótko a prawdziwie przez jednego tegoż narodu opisane, a na polski język przetożone jest od dawna znane w literaturze przedmiotu1. Dość obszerny, ponad dwustustronicowy tekst został wydany w formacie szesnastki w r. 1582 (taką informację znajdujemy w kolofonie), w poznańskiej oficynie Jana Wolraba, pierwszego spośród niemieckiej dynastii drukarzy osiadłych w Wielkopolsce ${ }^{2}$. Oficyna ta, która zastąpiła drukarnię Melchiora Neringa oskarżonego o sprzyjanie protestantom, działająca od r. 1578, tłoczyła wiele druków na zlecenie powstałego w 1573 r. w Poznaniu kolegium jezuickiego. Jego rektorem od chwili powstania do 1578 r. był Jakub Wujek. Dzieła autora Postylli były bardzo ważną częścią programu wydawniczego Wolraba, a drukowano je także wówczas, gdy poznańskim kolegium kierował już Jan Konarski (od 1579 r.), Wujek zaś podjął misję organizacji kolejnej jezuickiej placówki w Wilnie. Z drukarnią współpracował też intensywnie Hieronim Powodowski jako kanonik poznański będący często nakładcą (własnych) publikacji, obok Adama Paulinusa z Pobiedzisk i Jana Młodujewicza. Jako

1 Zob. m.in. W. Borowy, Prześladowani katolicy angielscy i szkoccy $w$ Polsce XVI wieku, „Przegląd Powszechny” 1938, 7-8, s. 121; M. Korolko, Klejnot swobodnego sumienia. Polemika wokót konfederacji warszawskiej w latach 1573-1658, Wydawnictwo PAX, Warszawa 1974, s. 155; H. Zins, Polska w oczach Anglików XIV-XVI, PIW, Warszawa 1974, s. 142; J. Tazbir, Prace wybrane, t. II: Okrucieństwo w nowożytnej Europie, Universitas, Kraków 2000, s. 98.

2 Por. Drukarze dawnej Polski od XV do XVIII wieku, t. 3, cz. 1: Wielkopolska, oprac. A. Kawecka-Gryczowa, K. Korotajowa, J. Sójka, Ossolineum, Wrocław 1977, s. 272. 
autorzy Wujek i Powodowski nadawali w istocie ton wydawnictwom Wolraba, skierowanym przede wszystkim przeciw innowiercom. Choć trzeba zauważyć, że drukowano tu również niektóre dzieła Skargi i jak stwierdza Alodia Kawecka-Gryczowa - przez „prasy poznańskie przeszły pisma wszystkich celniejszych pisarzy jezuickich tego czasu, zarówno polskich, jak i z Polską związanych, a także niektóre utwory zagranicznych polemistów zakonnych”3.

Być może to z osobą Hieronima Powodowskiego należałoby kojarzyć inicjatywę wydania Okrucieństwa kacyrskiego... Choć był duchownym diecezjalnym, łączyły go bliskie więzi z jezuitami (w rzymskim Collegium Germanicum uzyskał doktorat z teologii), przyjaźnił się i korespondował ze Skargą, a przesłanie przedmowy i przedstawiona w niej argumentacja pozostają zgodne ze stanowiskiem, jakie prezentował w innych swoich dziełach ${ }^{4}$. Kronika jezuitów poznańskich z lat siedemdziesiątych i wczesnych osiemdziesiątych XVI w. kilkakrotnie wspomina autora Wędzidta na sprośne btędy a bluźnierstwa nowych arianów, zawsze komplementując go jako człowieka, który był „obdarzony głęboką charyzmą w szerzeniu wiary, obsypany do tego wieloma godnościami kościelnymi, a przy tym jeszcze sławny powaga pobożnych ksiąg, jakie ogłosił drukiem" ". Poznański ksiądz kanonik, choć sam jezuitą nie był, często gościł na uroczystościach poznańskiego kolegium, wspierał jego studentów, cenili go i poważali ojcowie Towarzystwa Jezusowego.

Tekst Okrucieństwa... inkrustowany jest obficie cytatami biblijny$\mathrm{mi}$, lecz są one przytaczane w formie bliższej tradycji Biblii Leopolity (choć bynajmniej nietożsame z nia) niż późniejszej Biblii Wujka czy nawet (w wypadku Psalmów) Psałterza z 1593 r., co raczej przemawiałoby przeciwko ewentualnej współpracy samego Wujka. Należy jednak również rozważyć fakt, że do utworu dołączony został polski przekład ósmego rozdziału dzieła św. Cypriana z Kartaginy De Ecclesiae catholicae unitate, a to wskazywałoby na fakt, że autor/tłumacz był osobą o niemałej świadomości humanistycznej i patrologicznej. Ta translacja nie była, jak się zdaje, dotychczas brana pod uwagę w bar-

3 Ibidem, s. 273.

4 Zob. M. Korolko, Poglady polityczne i spoteczne Hieronima Powodowskiego, OiRwP 1967, 12, s. 87-97.

5 Kronika jezuitów poznańskich (mtodsza), t. I: 1570-1653, oprac. L. Grzebień SJ, J. Wiesiołowski, przeł. K. Kaczor, Wydawnictwo Miejskie, Poznań 2004, s. 43. 
dzo skromnych skądinąd badaniach nad osiągnięciami staropolskiej patrystyki ${ }^{6}$. Można domniemywać, że pozostaje ona zależna od znanej Erazmowej edycji pism św. Cypriana z 1520 r., lecz wymagałoby to osobnej analizy ${ }^{7}$. W każdym razie warto pamiętać — z jednej strony — o unikalności przekładu (pozostałe staropolskie translacje dzieł św. Cypriana to zaledwie fragmenty dwóch kazań, z których jeden, De coena Domini, znalazł się właśnie w Postylli Wujka) ${ }^{8}$, z drugiej zaś o swoistym patronacie, jaki nad wczesną polską patrystyką sprawował Hozjusz ${ }^{9}$. Wprowadzenie tego właśnie tekstu jako elementu swoistej ramy wydawniczej dzieła przydaje mu cech najściślej humanistycznych i być może nawet erazmiańskich. Należy też zauważyć, że Powodowski, wydając w 1578 r. u Szarffenberga swe dzieło Korab zewnętrznego potopu, dołączył do niego spolszczenie kazania św. Augustyna przeciwko opilstwu. Byłoby to więc rozwiązanie bardzo podobne do tego, którym posłużył się cztery lata później autor Okrucieństwa..., czyniąc tekst patrystyczny punktem odniesienia dla głównego wywodu przedstawionego w dziele.

Okrucieństwo kacyrskie... ukazało się w czwartym roku pracy oficyny Wolraba, z pewnością albo z inspiracji, albo za sprawą jezuitów, bo też jezuitą był autor oryginału, który — jak się wydaje — do tej pory pozostawał niezidentyfikowany w polskiej literaturze przedmiotu ${ }^{10}$. Już formuła tytułowa dziełka informuje, że jest ono przekładem tekstu na-

${ }^{6}$ Zob. przede wszystkim J. Fijałek, Przektady pism Grzegorza z Nazjanzu w Polsce. Wiadomość bibliograficzna i patrystyczna, cz. I „Polonia Sacra” 1918, 1, cz. 2 „Polonia Sacra" 1919, 3.

7 Zob. J. C. Olin, Erasmus and the Church Fathers, w: Id., Six Essays on Erasmus and a Translation of Erasmus' Letter to Carondelet (1523), Fordham UP, New York 1979, s. $36-47$.

8 Odnotowuje je (oraz dwie niemieckojęzyczne edycje królewieckie) cenna bibliografia: J. Czerniatowicz, C. Mazur, Recepcja antyku chrześcijańskiego w Polsce. Materiaty bibliograficzne, t. I: XVI-XVIII wiek, cz. 1: Autorzy i teksty, Towarzystwo Naukowe KUL, Lublin 1978, s. 43-44. Autorzy bibliografii nie uwzględnili jednak przekładu De Ecclesiae catholicae unitate dołączonego do Okrucieństwa kacyrskiego...

9 Por. M. Hanusiewicz-Lavallee, Czy byt i czym byt humanizm chrześcijański w Polsce?, w: Humanitas i christianitas $w$ kulturze polskiej, red. M. Hanusiewicz-Lavallee, Neriton, Warszawa 2009, s. 79-80.

10 Por. R. Koropeckyj, The Kiev-Mohyla Collegium and Seventeenth-Century PolishEnglish Literary Contacts: A Polish Translation of Henry Montagu's „Manchester al Mondo”, „Harvard Ukrainian Studies” 8 (1984), nr 1-2, s. 136-137. 
pisanego przez Anglika („przez jednego tegoż narodu opisane”). Podkreślają to również następujące słowa przedmowy:

Niech ci nie będzie ciężko, czytelniku miły, przeczytać tej małej książeczki, którą, od człowieka pobożnego, a przetoż i prawdziwego nieomylnie spisaną, a z obcego na język nasz przełożoną, ku twemu pożytkowi na świat wydawam $[\ldots] .^{11}$

Zastanawia formuła „z obcego na język nasz przełożoną”, wiele bowiem wskazuje na to, że podstawą translacji był tekst napisany po łacinie, ta zaś rzadko bywała charakteryzowana jako język „obcy”. Czyżby tłumacz posłużył się którąś z innych wersji językowych (o czym niżej)? Autor przedmowy mimochodem wprowadza też wzmianki wskazujące na fakt swoistych konsultacji, które weryfikują i dopełniają podawaną do druku relację: ,jako zinąd sprawę mam" ${ }^{12}$. Być może nie od rzeczy byłoby w tym kontekście przypomnieć, że w poznańskim kolegium od roku 1581 uczył greki oraz teologii moralnej rodowity Anglik z Lancaster, Laurentius Artur Faunteus (Arthur Lawrence Faunt, zwany też Arturem Anglikiem), autor licznych łacińskich dzieł polemicznych, apologetycznych i dydaktycznych, przeważnie wydawanych właśnie w oficynie Wolraba, silnie zaangażowany w zwalczanie herezji ${ }^{13}$. To on zapewne był bohaterem anegdoty opowiedzianej przez Jerzego Tyszkiewicza w Responsio[...] ad libellum famosum (Kraków 1615, w druk. M. Loba). Przedstawiała ona angielskiego jezuitę ni mniej ni więcej tylko jako apologetę przemocy religijnej ${ }^{14}$. $Z$ powodów religijnych zmuszony do opuszczenia ojczyzny, Faunt studiował najpierw sztuki wyzwolone w Lowanium, lecz studia teologiczne odbywał już w Rzymie i zakończył je w roku 1580. Był to właśnie rok, w którym z inicjatywy Williama Allena, późniejszego kardynała, a pod wodzą Roberta Personsa wyru-

11 Okrucieństwo kacyrskie przeciw katolikom w Anglijej, krótko a prawdziwie przez jednego tegoż narodu opisane, a na polski język przetożone, b. m. wyd., 1582 [Poznań, w druk. J. Wolbrama], k. c3r. (egz. Boss XVI.0.13).

12 Ibidem, k. d2v.

13 K. Estreicher, Bibliografia polska, stulecie XV-XVIII, Wydawnictwa UJ, Kraków 1898, t. XVI, s. 177-180. Zob. W. Borowy, op. cit., s. 115; Kronika jezuitów poznańskich (mtodsza), t. I: 1570-1653, s. 71.

14 Zob. W. Sobieski, Nienawiść wyznaniowa ttumów za rządów Zygmunta III, Warszawa 1902, s. 85-86. 
szyła do Anglii sławna misja jezuicka. To z nią właśnie i jej tragicznymi dziejami związany jest pierwowzór Okrucieństwa kacyrskiego... Czyżby to Arthur Faunt był „konsultantem” tłumacza i/lub autora przedmowy dzieła?

Jest ono, jak się okazuje, przekładem epistolarnej relacji samego Roberta Personsa (vel Parsonsa), której pierwsze wydanie ukazało się w nadzorowanej przez niego drukarni George'a Flintona w Rouen w 1581 r. pod tytułem De persecutione Anglicana epistola, qua explicantur afflictiones, aerumna, [et] calamitates gravissimae, cruciatus etiam [et] tormenta [et] acerbissima martyria, quae Catholici nunc Angli ob fidem patiuntur. Już w r. 1582 dziełko zostało wydane w Paryżu u Thomasa Brumena, co najmniej dwukrotnie w Rzymie - u Francesca Zanettiego oraz u Giorgia Ferrariego, pod tytułem De persecutione Anglicana libellus..., następnie, w tymże samym 1582 r., w Ingolstadt u Edera jako De persecutione Anglicana commentariolus. Pojawiły się też niemal natychmiast wersje w językach narodowych - francuska, sporządzona przez Matthieu de Launoy i wydana również w r. 1582 u Brumena w Paryżu, włoska (tłumacz nieznany), opublikowana w 1582 r. w Bolonii u Alessandra Benacciego, niemiecka, przetłumaczona przez Johanna Christoffa Huebera, ogłoszona w Ingolstadt u Davida Sartoriusa w 1583 r., a przede wszystkim angielska, przełożona z francuskiego (o czym informuje już karta tytułowa) przez tłumacza podpisującego się inicjałami G. T., skolacjonowana z oryginałem łacińskim, opatrzona obszernym listem do członków Rady Królewskiej i wydana w tej samej oficynie Flinotona, w której ukazała się wersja oryginalna (fałszywy adres wydawniczy wskazywał na Douai w Artois) ${ }^{15}$.

Robert Persons, który bywa uważany za jednego z najświatlejszych intelektualistów wczesnonowożytnej Anglii, ale też, ze względu na swą działalność polityczną i rolę, jaką odegrał w przygotowaniu inwazji hiszpańskiej na Anglię, traktowany jest jako postać co najmniej kontrowersyjna i wręcz modelowy przykład „podstępnego jezuity”, opuścił ojczyznę, gdy dotknę-

15 Zestawienie wydań i tłumaczeń De persecutione... podaje Victor Houliston. Por. Id., Catholic Resistance in Elizabethan England. Robert Persons's Jesuit Polemic, 1580 1610, Ashgate - Institutum Historicum Societatis Iesu, Burlington - Roma 2007, s. 195. Houliston nie uwzględnił w tym wykazie rzymskiej edycji Giorgia Ferrariego ani też polskiej translacji. Zob. także The Contemporary Printed Literature of the English Counter-Reformation Between 1558 and 1640, ed. A. F. Allison, D. M. Rogers, Scolar Press - Gower Pub., Aldershot - Brookfield 1989-1994, t. 1, poz. 874-884. 
ły go prześladowania religijne, a wierność katolicyzmowi uniemożliwiła dalszą edukację ${ }^{16}$. Zafascynowany duchowością św. Ignacego, w Rzymie wstąpił do jezuitów. Wyznaczony na przywódcę misji jezuickiej w Anglii, wraz z późniejszym świętym, wezwanym wówczas z Pragi o. Edmundem Campionem, Persons udał się do Anglii w kwietniu 1580 r. i dotarłszy do Londynu, rozpoczął tam niezwykle dynamiczną działalność duszpasterską, założył nielegalną „latającą” drukarnię (oficyna Stephena Brinkleya), odbywał podróże misyjne, pozyskiwał kolejnych konwertytów, wreszcie pisał. To właśnie w Londynie u Brinkleya ukazała się jego pierwsza książka, Reasons of Refusal (1580), następnie Brief Censure (1581), A Discoverie of I. Nicols Minister, Misreported a Jesuite (1581). Tu także w czerwcu 1581 r. wydrukowano Rationes decem Campiona. Zaledwie kilka tygodni po wydaniu tekstu (w lipcu) Campion został aresztowany i osadzony w Tower, Personsowi jednak udało się zbiec najpierw do Sussex, potem do Rouen, gdzie wkrótce uruchomił wydawnictwo, które miało kontynuować działalność drukarni Brinkleya. 1 grudnia 1581 r. odbyła się egzekucja o. Campiona, Persons zaś, rozpoczynając kolejny etap działalności duszpasterskiej, pisarskiej i politycznej, przedstawił opinii publicznej na kontynencie dramatyczne świadectwo męczeństwa katolików angielskich i swego towarzysza.

Dla potrzeb niniejszego studium udało mi się przebadać zaledwie dwie łacińskie edycje z r. $1582^{17}$ oraz przekład angielski ${ }^{18}$. Te dwie

16 Na temat Personsa zob. np. V. Houliston, op. cit.; Id., Robert Persons's Comfortable History of England, w: Martyrs and Martyrdom in England, c. 1400-1700, ed. T. S. Freeman, T. F. Mayer, Bodell Press, Woodbridge 2007, s. 180-202; F. Edwards, Robert Persons: The Biography of an Elizabethan Jesuit, 1546-1610, Institute of Jesuit Sources, St Louis 1995; M. L. Carafiello, Robert Parsons and English Catholicism, 1580-1610, Associated University Presses, Cranbury - London - Ontario 1998; T. M. McCoog SJ, The Society of Jesus in Ireland, Scotland and England 1541-1588: „Our Way of Proceeding”, Brill, Leiden 1996, passim; B. Basset, The English Jesuits from Campion to Martindale, Action Publishing, Gloucester 2004.

17 De persecutione Anglicana libellus, quo explicantur affictiones, calamitates, cruciatus, et acerbissima martyria, quae Angli catholici nunc ob fidem patiuntur, quae omnia in hac postrema editione aeneis typis ad vivum expressa sunt, Roma 1582, w druk. G. Ferrariego (egz. Boss XVI.0.9700); De persecutione Anglicana commentariouls, Ingolstadt 1582, w druk. Edera; skan dostępny w zasobach Bayerische Staatsbibliothek Digital http://reader.digitale-sammlungen.de/en/fs1/object/display/bsb10193295_00001. html (data odczytu 24.11.2012).

18 An Epistle of the Persecution of the Catholickes in Englande translated out of Frenche into Englishe and conferred withe the Latyne copie by G. T. [...], Douai, b. r. wyd. [Rouen 1582, w druk. G. Flintona] (egz. Bodleian Library 11127 e. 53/125). 
pierwsze okazują się niemal identyczne, lecz wersja angielska różni się od nich znacznie w swych ostatnich partiach, co wynika z faktu, iz jak sądzę - An Epistle of the Persecution of the Catholickes in Englande może być świadkiem archetypu tekstu, sporządzonego przez Personsa przecież jeszcze w r. 1581 (taka jest bowiem data wydanego w Rouen pierwodruku, do którego jednak, niestety, nie udało mi się dotrzeć). Egzekucja Campiona odbyła się, jak wspomniałam, dopiero 1 grudnia tegoż roku, a zatem Persons opracowywał swoją relację niemal natychmiast po dotarciu na kontynent (ostatnie datowane, zawarte tu informacje odnoszą się do sierpnia $1581 \mathrm{r}$.), ale jeszcze przed śmiercią towarzysza. Nic zatem dziwnego, że w An Epistle... mowa o jego uwięzieniu i torturach, lecz nie o męczeństwie — o nim informuje pochodzący od tłumacza dodatek The Translator to the Gentle Reader. Ponieważ edycje łacińskie z r. 1582 czynią opis egzekucji Campiona, Alexandra Brianta i Ralpha Sherwina integralnym elementem narracji, można sądzić, że na przełomie 1581 i 1582 r. Parsons sporządził drugą redakcję tekstu, która dawała już pełny opis wydarzeń. Polskie Okrucienstwo kacyrskie jest oparte właśnie na tej drugiej redakcji, utrwalonej m.in. w cytowanej tu edycji rzymskiej i niemieckiej ${ }^{19}$.

Polska wersja dzieła zmienia ramę wydawniczą, która konsekwentnie zachowywana była w analizowanych przeze mnie edycjach. Tekst łaciński poprzedzał list dedykacyjny do kardynała Filippa Boncompagna, translację angielską zaś — obszerny list tłumacza do członków Rady Królewskiej. Po zamknięciu właściwej relacji Personsa w edycjach łacińskich następowały: list adresata dzieła, Gerarda, oraz list Alexandra Brianta do ojców Towarzystwa Jezusowego (De persecutione Anglicana libellus uzupełniona jeszcze była tłoczonym u Wincentego Accolta dodatkiem; po wierszu łacińskim Presentis Ecclesiae Anglicanae Typus znajduje się cykl sześciu pełnostronicowych, wstrząsających miedziorytów, ilustrujących kolejne etapy uwięzienia, tortur i męczeńskiej śmierci Campiona, Brianta i Sherwina). Przekład angielski, jak wspomniałam, dodawał jeszcze ów list tłumacza opisujący śmierć Campiona i towarzyszy.

Z tej ramy wydawniczej polski tłumacz zachował jedynie list Gerarda, tytułując go wszakże Przypomnienie, należące $k$ temu listowi, tego, do kogo byt pisany, co wynika z konsekwentnego unikania imiennych

19 Por. De persecutione Anglicana libellus...; De persecutione Anglicana commentariouls... 
zwrotów do adresata pojawiających się w całym tekście pierwowzoru. W miejsce pominiętych elementów polski autor wprowadza nowe całkowicie oryginalną przedmowę, czyli obszerną Przemowę ttumaczowa czytelnikowi potrzebna, oraz wspomniany już przekład fragmentu dzieła św. Cypriana z Kartaginy. Warto też zauważyć, że realia angielskie, choć bynajmniej nie zostały w dziele zatarte, to jednak z pewnością eksponowane były z mniejszą siłą niż w wydaniach łacińskich (jeszcze dobitniej w angielskim), które wprowadzały marginalia identyfikujące bohaterów narracji, zarówno męczenników, jak i ich denuncjatorów i oprawców. Dzieło bowiem jest proponowane polskiemu czytelnikowi bynajmniej nie jako pretekst i instrument jakiejś mrocznej delectatio morosa (do czego się zresztą słabo nadaje) i nie tyle nawet jako nośne propagandowo oskarżenie angielskiej tyranii, ile jako głos w teologicznym sporze o męczeństwo, który rozgorzał właśnie w Europie i w który włączali się również polscy autorzy.

Historyja o srogim prześladowaniu Kościoła Bożego Cypriana Bazylika wprowadziła do polskiego obiegu czytelniczego najważniejsze protestanckie martyrologia szesnastowiecznej Europy, z Crespinem, Pantaleonem i Foxem na czele, i budowała obraz Kościoła apokaliptycznego, w którym rzesze męczenników, poległe z rąk Antychrysta, gromadzą się wokół Baranka jako ci, co „broniąc statecznie prawdy Syna Bożego, wedle miarki łaski Bożej na on czas im od Boga danej, garła swe z wielką statecznością i z podziwieniem przeciwników położyli" ${ }^{20}$. Po drugiej stronie wielkie dzieło hagiograficzne Piotra Skargi przedstawiało czytelnikom historię szesnasto-, później zaś siedemnastowiecznych męczenników katolickich, wśród których ofiary prześladowań za rządów Tudorów i Jakuba I stawały w pierwszym szeregu świętych wiernych prawdziwemu, bo od wieków trwającemu Kościołowi. Sobór trydencki przyczynił się do bardziej wyrazistej niż na początku stulecia konfrontacji nowożytnych martyrologiów (którymi początkowo zawładnęli protestanci), czemu towarzyszyła również, po stronie katolickiej, odnowa kultu świętych męczenników pierwszych wieków chrześcijaństwa ${ }^{21}$. Po pojedynczych relacjach, które publikowano na przykład po śmierci Johna Fishera czy Thomasa More'a, przyszła pora na dzieła obszerniejsze,

20 C. Bazylik, Historyja o srogim prześladowaniu Kościota Bożego [...], Brześć Litewski 1567, w druk. Radziwiłłowskiej, s. 2, 4 (egz. BUW Sel. 612.113).

21 Por. B. S. Gregory, Salvation at Stake. Christian Martyrdom in Early Modern Europe, Harvard UP, Cambridge, Mass. - London, s. 250 i n. 
takie jak rekomendowane do lektury przez samego Skargę (w Żywotach świętych) dzieło Johna Fenna i Johna Gibbonsa (uzupełnione w późniejszych wydaniach przez Johna Bridgewatera) Concertatio Ecclesiae catholicae in Anglia (1583) czy napisane pod patronatem Filipa II i wydane starannie u samego Plantina martyrologium Richarda Verstegana Theatrum crudelitatem haereticorum nostri temporis (1588), pomyślane jako katolicka odpowiedź na dzieło Foxa ${ }^{22}$. Tekst Personsa był bodaj pierwszą obszerniejszą, w istocie syntetyczną relacją, a zatem jego spolszczenie miało niebagatelną rolę dla polskiej dyskusji o męczennikach i Kościele prawdziwym.

Przedmowa do Okrucieństwa kacyrskiego... eksponuje z wielką siłą teologiczną problematykę męczeństwa, lecz zarazem podkreśla jej ambiwalencje, bo przecież polscy czytelnicy dzieła znali już dobrze (choćby dzięki Bazylikowi) martyrologia protestanckie i przykłady stosowania przymusu wyznaniowego ze strony katolickiej:

Bo jako na on czas Mojżesz, choć nad onym ludem swym a krwią swoją, jednak dla tak wielkiej krzywdy Boskiej musiał użyć wielkiej srogości w pokaraniu a wybiciu ich, tak i teraz przełożeni krześcijańscy na to mają od Boga miecz powierzony, aby go ku hamowaniu takiego niezbożnego zuchwalstwa używali. Co jako takie urzędy od Boga dane Bogu kwoli czynią, tak zasię kacyrze, mimo taką moc od Boga daną, z poduszczenia szatańskiego a zawaśnienia swego nad katolikami okazują. Ale między takowym karaniem kacyrskim a katolickim wielką różność opisuje Augustyn św., pokazując z Pisma św., iż jedno prześladowanie jest niesprawiedliwe, o którym ono Dawid tak pisze: „Niesprawiedliwie prześladowali mię, przetoż wspomóż mię", drugie zasię sprawiedliwe, o którym tak mówi: „Będę prześladował nieprzyjacioły moje, ani tego poprzestanę, aż oni ustaną, ${ }^{23}$

I dalej, powołując się wciąż na św. Augustyna:

Jeszcze tenże doktor potwirdza nauką Zbawiciela naszego, gdy zowie być błogosławionymi, którzy cierpią prześladowania dla sprawiedliwości, lecz żadną miarą nie mogą cierpieć dla sprawiedliwości ci, którzy wiary prawdziwej nie

22 Por. R. Oates, Elizabethan Histories of English Christian Origins, w: Sacred History. Uses of the Christian Past in the Renaissance World, ed. K. Van Liere, S. Ditchfield, H. Louthan, Oxford UP, Oxford 2012, s. 174.

23 Okrucieństwo kacyrskie..., k. A4v-A5r. 
mają, i owszem, Kościół Boży rozerwali. Bo co mi to za sprawiedliwość, gdy plewa kacyrska, porwawszy się z wiatrem płochego błędu swego, czyste wiary powszechnej ziarna za sobą pociąga abo (co gorszego jest) z Pańskiej stodoły wypycha? Otóż Kościół powszechny błogosławiony jest, który cierpi od kacyrzów prześladowanie dla sprawiedliwości, a kacyrze zaś nieszczęsnymi są, gdy cierpią utrapienie przez niesprawiedliwość swoję. [...] Przeto (jako tenże Doktor św. pisze) męczennika czyni causa, non poena, to jest zawinienie, nie karanie. ${ }^{24}$

Fizyczne prześladowanie protestantów okazuje się więc jak najbardziej usprawiedliwione; owszem, trzeba zachęcać szlachtę, by „użyła miecza" wobec swoich poddanych, jeśli zbłądzą w sprawach wiary, gdyż będzie to w istocie aktem miłości chrześcijańskiej (miłością jest bowiem jedność z Kościołem powszechnym, o czym pouczał św. Cyprian). A że władza świecka bywa, niestety, opieszała w owym miłosiernym strofowaniu odstępców (czemu winna jest konfederacja warszawska), nie należy się dziwić, iż Bóg posługuje się czasem „motłochem ludzkim”, by pohamować bluźnierców. W tym kontekście wygłoszona zostaje ni mniej ni więcej tylko pochwała tumultu krakowskiego z r. 1574, który i tak okazuje się — zdaniem autora przedmowy — mniej znaczący niż ograbienie i złupienie wielu świątyń katolickich w dobrach polskich protestantów ${ }^{25}$. Ten motyw strat materialnych Kościoła ponownie kieruje myśl ku Powodowskiemu, dla którego był to zawsze temat istotny ${ }^{26}$.

Apologia przymusu wyznaniowego zastosowanego w słusznej sprawie służy przede wszystkim dyskredytacji autorów wyliczających „nam swoje męczenniki w prześladowaniu nie wiem jakie" ${ }^{27}$. To denuncjowanie fałszywych męczenników i odróżnienie ich od prawdziwych było koniecznym, niemal topicznym elementem kontrowersji martyrologicznych tego czasu. Dla obu stron sporu kryterium pozostawała doktryna — co dobitnie wyrażała sentencja św. Augustyna przywołana przez polskiego autora: Martyrem facit non poena, sed causa (Sermo de uno martyre) — weryfikacja prawdziwości nauczania również jednak z oczywistych powodów wymagała zasto-

24 Ibidem, k. A6r-k. A6v.

25 Zob. ibidem, k. C2v. Aprobatę dla zburzenia „brogu krakowskiego” wyrażał m.in. sam Hozjusz. Zob. W. Sobieski, op. cit., s. 32; J. Tazbir, Państwo bez stosów. Szkice z dziejów tolerancji w Polsce XVI i XVII wieku, Iskry, Warszawa 2009, s. 102.

26 Por. M. Korolko, Poglady polityczne i spoteczne Hieronima Powodowskiego, s. 92.

27 Okrucieństwo kacyrskie..., k. B3v. 
sowania jakichś kryteriów ${ }^{28}$. Męczeństwo potwierdzone przez odwołanie się do kryteriów pozadoktrynalnych mogłoby zatem, paradoksalnie, stać się argumentem na rzecz prawdziwości doktryny. Tym objaśnić należy uwzględnianie wyznaczników behawioralnych, takich jak stałość i cierpliwość w obliczu tortur i śmierci, choć zarazem i protestanci, i katolicy przyznawali - nie wyrzekając się stosowania tych kryteriów — że nie są one rozstrzygające. Jeśli w tej kontrowersji teologowie i pisarze katoliccy dysponowali jakimiś argumentami specyficznymi (lub przynajmniej bardziej charakterystycznymi), to polegały one na wskazaniu cudów pośmiertnych, akcentowaniu statusu społecznego i wykształcenia ofiar, wreszcie na silniejszym eksponowaniu uzasadnień zaczerpniętych z tradycji patrystycznej, zwłaszcza zaś z pism św. św. Augustyna i Cypriana oraz Tertuliana ${ }^{29}$.

Rama wydawnicza zaproponowana przez polskiego tłumacza dzieła Personsa wprowadzała je zatem w ortodoksyjny kontekst teologiczny, który dopełniał i wzmacniał siłę świadectwa historycznego odnoszącego się nie tyle do tytułowego „okrucieństwa” prześladowców, ile właśnie do męczeństwa katolickich wyznawców. Co do tych pierwszych, zauważyć trzeba, że stosunek do nich bywa tu ambiwalentny, czego dowodzi nie tylko właściwy tekst dzieła, pisanego przecież przez Anglika, ale i polska przedmowa, np.

Ale jeśli który naród krześcijański miał wielkie zalecenie w pobożności, baczeniu a ludzkości, był też w tym niepodlejszy naród Anglików [...]. I teraz z strony baczenia świeckiego nie zeszło nic narodowi temu, bo królowa ich, chocia białagłowa, ma w sobie takie snadź męskie dzielności, iż jako virago, w świeckim sprawowaniu królestwa żadnemu przełożonemu chrześcijańskiemu naprzód nie da. Lud także onego narodu w wielu innych cnotach i dzielnościach nie stracił dotąd onej dawnej sławy swej. ${ }^{30}$

${ }_{28}$ Tę samą maksymę przywołał także we wstępie do Przydatku do tych żywotów o świętych męczennikach, którzy tych naszych wieków dla Chrystusa, prawdy i Kościoła Jego świętego cierpieli Piotr Skarga, przypisując ją jednak św. Cyprianowi: „Nie męka (jako mówił stary św. Cypryjan, gdy się także heretykowie z swoich męczenników fałszywych chlubili), ale przyczyna męczennika czyni”. To dość osobliwa pomyłka, tym bardziej że w dalszej części swego tekstu Skarga wyraźnie się inspiruje wywodem św. Cypriana i przywołuje te same cytaty biblijne (P. Skarga, Żwoty świętych Starego i Nowego Zakonu, Kraków 1585, w druk. A. Piotrkowczyka, s. 1124) (egz. Boss XVI.F. 4651).

29 Por. B. Gregory, op. cit., s. 320-331.

30 Okrucieństwo kacyrskie..., k. C5v-k. C6r. Na temat wyrażonych tu negatywnych opinii o Elżbiecie zob. także J. Tazbir, Elżbieta I we wspótczesnej jej opinii polskiej, OiRwP, 1989, 34, s. 51-52. 
Omówienie samego „okrucieństwa” jest i w przedmowie, i w samym dziele rzeczowe, a przy tym dość oszczędne. Obok niemal „technicznego" opisu kary, którą angielskie prawo od czasów średniowiecza przewidywało dla zdrajców, a na którą skazywano katolików, znajdujemy tu od razu argumenty charakterystyczne dla katolickiej apologii nowożytnych męczenników - wskazanie na cuda i liczne nawrócenia będące owocem bohaterskiej śmierci wyznawców, na ich dzielność w obliczu śmierci oraz caritas przeżywaną w łączności z Kościołem:

Bo (iż insze opuszczę) ta jest takowych pospolita męka. Naprzód po długim a barzo ciężkim więzieniu męczą go ciągnieniem, przedtym światu niesłychanym. Bo położywszy go na krosnach do tego uczynionych, zadzierzgują mu stryczki u ostatnich stawów, tak u ręku, jako i u nóg, zatym czterema kołowrotkami przeciw sobie rościągają tak długo, aż się one członki z stawów wyrwą. Potym zakładają one stryczki do drugich za tym idących stawów, aż każdy z osobna wytargają, póki ich jedno stawa. Tak już utarganego włożą na jakieś sanie i włóczą po ulicach. Przywiozą go potym na miejsce męki i na wysoki złoczyński majestat do tego zbudowany go wprowadzą, gdzie, naprzód przed wszytkim ludem złoczyńcą a zdrajcą rzeczypospolitej jako nasromotniej obwołanego, na szubienicy tamże zgotowanej go obieszą. A gdy się już namęczywszy, konać pocznie, tedy go z powrozem utną i zaś roztrzeźwią. Dopiero znowu urżną mu wstydliwe członki, a za tym rozporzą go, i dobywszy serca i wnętrzności, a to wszystko zaraz spaliwszy, na koniec go rozsiekają na sztuki, które po różnych częściach miasta na palach rozwieszaja, a osobliwie głowę, którą pierwej obwarzą, a to dlatego (jako zinąd sprawę mam), iż niekiedy głowy takowych męczenników na tych palach wystawione, przez jakieś cudo okazowały się być świeże i jakoby żywe, za czym ludzie wiary powszechnej, których tam jest, choć zatajonych, niemało, katolikami się być opowiadali i inszy się do nich nawracali, i spólnie przeciw takiemu okrucieństwu powstawali. Jakoż im tam takowego okrucieństwa i prześladowania więcej przybywa, tym się też więcej ludzi na wiarę powszechną nawraca, widząc, jako ci niewinni ludzie, a tak haniebnie i sromotnie mordowani, takowe męki z dziękowaniem Bogu i modleniem się za mordowniki swoje mężnie i ochotnie podejmują. [...] Bo jako powiedział Tertulianus, krew męczenników jest nasienie krześcijanów. ${ }^{31}$

Oryginał dzieła ma formę listu skierowanego do przyjaciela, wymienionego z imienia zarówno w edycjach łacińskich, jak i w przekładzie

31 Okrucieństwo kacyrskie..., k. Dv.-k. D3v. Por. B. Gregory, op. cit., s. 320-328. 
angielskim (Gerard z Bolonii), co pomija się w wersji polskiej. Tłumacz zachowuje jednak wszystkie pozostałe cechy stylistyczne listu, intymność zwrotu do przyjaciela, któremu z niepewnością powierza się bolesną tajemnicę w odpowiedzi na nalegania $\mathrm{z}$ jego strony:

\begin{abstract}
Częste listy brałem od ciebie o jednejże jakmiarz rzeczy, bo prosisz i barzo mi nalegasz, abych ci pisaniem oznajmił, co bych pewnego a doświadczonego miał o prześladowaniu katolików w Anglijej, o którym piszesz, iż tam u was jest posłuch nieleda jaki, wszakoż nie do końca dowodny ani pewną sprawą utwierdzony, rozumiejąc to o mnie jako o tym, który bliżej tego będąc i co się tam na każdy dzień dzieje wiadomość miewając, mógł bych cię o tych rzeczach pisaniem swym upewnić. ${ }^{32}$
\end{abstract}

Dalej narrator przedstawia motywy sporządzenia swojej relacji — zabezpieczenie się przed potwarzami strony przeciwnej, w istocie bowiem De persecutione... już w momencie swego powstania było uwikłane zarówno w teologiczny spór dotyczący fałszywego i prawdziwego męczeństwa, jak i w doraźną polemiką związaną z oceną moralno-prawną egzekucji, których ofiarami padali protestanci na kontynencie, katolicy zaś w Angliii ${ }^{33}$. Jego intencją jest danie świadectwa, lecz wpisanego w inny niż ten właściwy protestantom typ dyskursu:

Baczę się bowiem w tym, iż nam, którzy się powszechnego Kościoła starodawnego trzymamy, nie godzi się krzywdy krzywdą wetować, ani też złości przeciwników naszych popędliwością mowy naprawować. ${ }^{34}$

32 Cyt. Okrucieństwo kacyrskie..., s. 1. Por. „Frequentes a te litteras argumenti non dissimilis recepi, petis enim et vehementer urges, ut scriptione significem, quae mihi certa sunt et explorata, de Anglicana in orthodoxos persecutione, cuius tu istic famam esse non exiguam quidem, sed minime tamen explicatam, et fidei parum constantis, affirmas" (De persecutione Anglicana libellus..., s. 7).

33 Por. V. Houliston, op. cit., s. 29-30. Pierwsze z serii pism Personsa podejmujące problematykę męczeństwa, The Copie of a Double Letter... containing the true aduises of the cause, and manner of death of one Richerd Atkins, executed by fire in Rome (Rheims 1581), dotyczyło anglikańskiego męczennika uwięzionego i spalonego w Rzymie 2 VIII 1581.

34 Okrucieństwo kacyrskie..., s. 5. Por. „Non enim arbitror nostrum esse, qui fidem Christi catholicam amplexamur, iniuriam iniuria compensare, aut malefactorum iniquitatem, orationis velle acerbitate castigare" (De persecutione Anglicana libellus, s. 9). 
Ma to więc być retoryka caritatis, nie zaś nienawiści, narracja o prześladowaniach służyć winna prawdzie i sprawiedliwości, umacnianiu słabych i nawróceniu zbłąkanych. Ten argument dotyczący właśnie $c a-$ ritatis, urzeczywistnianej w jedności z Kościołem, wydaje się szczególnie ważny, gdyż w kontekście teologii św. Cypriana to on właśnie pozwala orzekać o „prawdziwości” aktu męczeństwa ${ }^{35}$.

Tekst polski nie jest adaptacją, lecz przekładem. Choć Persons nigdzie (podobnie zresztą jak w oryginale łacińskim) nie zostaje wymieniony z imienia, to pozostaje oczywiste, iż narrator jest Anglikiem, a cała relacja odnosi się do jego doświadczeń w ojczyźnie; to opowieść o tym, „co katolikowie w naszej Anglijej cierpią" i co się dzieje „w pojśrzod$\mathrm{ku}$ a prawie w oczu braciej narodu naszego" ${ }^{36}$. Zaprezentowanie tekstu Persona w całej jego autentyczności miało, rzecz jasna, pierwszorzędne znaczenie perswazyjne, jako głos spośród ucisku i prześladowań, który sam w sobie winien być przestrogą dla Polaków, naiwnie ufających tolerancyjnym zapisom konfederacji, gdy tymczasem „kacerze” nieuchronnie wszędzie wprowadzają „krwie rozlanie”, a „kto Bogu wiarę złamał, niepodobna, aby ją człowiekowi strzymać mial" ${ }^{37}$.

Relacja Personsa, co warto zauważyć, bynajmniej nie epatuje obrazami okrucieństwa. Wiele miejsca zajmuje w niej skrupulatne omówienie aktów prawnych wymierzonych przeciwko katolikom oraz wywód zmierzający do wykazania, jak wielkim nadużyciem jest w prawodawstwie angielskim utożsamienie zdrady stanu z samym faktem wierności wyznaniu katolickiemu. Absurdalność tej sytuacji oraz dysproporcje winy i kary ilustruje przykładami. Tak kształtuje się właściwe martyrologium, świadectwo męstwa i stałości wyznawców, świętych bożych:

Ale proszę, gdzież mi jest milej być jako z naszymi? a cóż mówię: $\mathrm{z}$ naszymi, i owszem, z Krystusa, Boga i Zbawiciela namilszymi, których żywot jest świattością naszą, ich stałość jest przykładem naszym, ich mężność ozdobą i sławą naszą, na koniec ich śmierć jest chwałą naszą. Przetoż wyznawam to, iż chociam jest ciałem odległy, duchem jednak zawsze mieszkam z nimi i nigdy z umysłu mego nie wychodzą. ${ }^{38}$

35 J. Patout Burns, Jr., Cyprian the Bishop, Routledge, London - New York 2002, s. 69.

36 Okrucieństwo kacyrskie..., s. 6.

37 Ibidem, k. B4v.

38 Ibidem, s. 86-87. Por. „At ubi sim (quaeso) libentius quam cum nostris? Quid dico: nostris? Immo cum Christi Dei et Salvatoris amicissimis, quorum vita - lux 
Narrator przedstawia zatem losy pojmanych, torturowanych i skazywanych na śmierć katolików, rzadko wymienianych z imienia już w samym tekście głównym (i tylko te nazwiska zachowane są w przekładzie polskim), w oryginale łacińskim najczęściej jednak identyfikowanych za pomocą not marginalnych (bogactwem szczegółów wyróżnia się w tym zakresie wersja angielska). Daje swoisty przewodnik po więzieniach i twierdzach, podaje ( $\mathrm{w}$ marginaliach) nazwiska denuncjatorów, oprawców, anglikańskich ministrów i polemistów. I tak opowiada o londyńskiej Tower, „w którą więc zdrajce sadzano, teraz ma dosyć kapłanów”39, o więzieniach w York („twierdza eboraceńska”), w Hull („twierdza hultoneńska”), w kornwalijskim Lanson („twierdza lansoneńska w powiecie kornubeńskim”), o „wieży, którą Bechanija zową” (Beauchamps tower $)^{40}$. Poznajemy przejmujące historie Johna Coopera, Thomasa Sherwooda, Williama Thyrwitta, Roberta Dymoke'a, Magdaleny Thymbleby, Thomasa Pounde'a, Edwarda Hansego i oczywiście Edmunda Campiona. Są to najwyraźniej informacje z pierwszej ręki („Żywi jednak są ci, którzy się temu przypatrowali, i mógłbym je mianować, gdyby im to było bezpieczno" $)^{41}$, dotyczą wydarzeń, które rozgrywały się około r. 1580, a więc najbardziej aktualnych, tam zaś, gdzie narrator nie ma pewności co do ich przebiegu, daje temu wyraz, np.:

Bo słusznie opuściłem i zamilczałem więcej takich rzeczy, niżem ich tu opisał, [...] częścią, iż pewna wszystkich rzeczy wiadomość za czasów i rzeczy tak zatrudnionych mieć się nie może $[\ldots] .42$

Persons jest powściągliwy w opisach okrucieństwa oprawców, raczej unika szczegółowych deskrypcji egzekucji („dokonali go innymi męka-

nostra, constantia - exemplum nostrum, fortitudo - decus et honor noster, mors denique - gloria nostra. Unde, fateor, quod licet absim corpore, spiritu tamen semper versor cum illis, nec unquam animo elabuntur meo" (De persecutione Anglicana libellus..., s. 55).

39 Ibidem, s. 56.

40 Ibidem, s. 57-59, 72.

41 Ibidem, s. 73. Por. „Vivunt tamen qui hoc oculis viderunt et nominari a me possent, nisi illis esset periculosum” (De persecutione Anglicana libellus..., s. 47).

42 Ibidem, s. 130. Por. „Plura enim longe silenda mihi et praetermittenda fuerunt, quam his litteris tradenda [...] partim, quia certa plurimorum cognitio, his temporum et rerum difficultatibus, haberi non potest [...]" (De persecutione Anglicana libellus..., s. 79). 
mi, które zdrajcom Rzeczypospolitej są zwyczajne” — tak oszczędnie pisze na przykład o kaźni zgładzonego w 1579 r. Thomasa Sherwooda), a wyjątkiem będzie tu, oczywiście, najbardziej aktualna, poruszająca go w sposób szczególny informacja o śmierci Campiona, Brianta i Sherwina (być może oparta na relacji opublikowanej we Francji już pod koniec grudnia 1581 r. $)^{43}$. Wiele uwagi poświęca problemowi dysput teologicznych, do których angielscy ministrowie wzywają katolików, choć zarazem drukowanie książek katolickich czy jawne głoszenie doktryny katolickiej grozi niechybnym uwięzieniem i śmiercią. Dysputy zatem odbywają się głównie w więzieniach, a stają do nich poddawani wcześniej (i później) torturom duchowni. Obok opisu sławnych dysput więziennych Edmunda Campiona, znajdujemy tu wiele innych, w tym także opis niedoszłej dysputy Jamesa Bosgrave’a, młodego wówczas wileńskiego profesora matematyki, który, przybywszy do Anglii w 1580 r., zadenuncjowany przez Johna Rogersa, trafił do więzienia i — oskarżony w procesie Campiona — został skazany na śmierć, lecz wykonanie wyroku w ostatniej chwili zawieszono i Bosgrave'a odesłano ponownie do Tower. Dopiero na skutek interwencji dyplomatycznej Batorego karę zamieniono na wygnanie, co pozwoliło więźniowi na po-

43 Już 14 I 1582 r. Henry Cobham dołączył do listu skierowanego do Francisa Walsinghama ogłoszoną po francusku, a zawierającą opis śmierci Campiona i jego towarzyszy książkę, którą — wedle jego relacji — publicznie kolportowano „in the streets with outcries, naming them to be cruelties used by the Queen in England" (Calendar of State Papers, Foreign Series, of the Reign of Elizabeth, January 1581-April 1582, ed. A. J. Butler, Mackie and Co., London 1907, no 508). Pierwszą wzmiankę o tym dziełku zawiera już list Cobhama pisany 4 I (ibidem, no 491). Malcolm Smith uważa, że mowa tu o L'histoire de la mort que le $R$. $P$. Campion prestre de la compagnie du nom de Jesus, et autres ont souffert en Angleterre pour la foy Catholique et Romaine le premier jour de Decembre, 1581 (Paris 1582, w druk. Guillaume'a Chaudiere'a) i twierdzi, że tekst ten, choć przełożony z angielskiego (o czym informuje podtytuł), nie jest przekładem najpowszechniej później wykorzystywanej translacji Thomasa Alfielda (M. Smith, Ronsard and Queen Elizabeth I, w: Id., Renaissance Studies, Articles 1966-1994, Droz, Genève 1999, s. 30). Stwierdzenie, na czyjej relacji oparł się Persons, przygotowując drugą redakcję De persecutione Anglicana..., i czy znajdujemy tu interpolacje zaczerpnięte od innych autorów, wymagałoby osobnych badań. W każdym razie jego dzieło (jako tekst o nieustalonej atrybucji i przypisywany raczej Williamowi Allenowi) również trafiło do rąk sir Walsinghama i zostało wspomniane w jego korespondencji z Cobhamem (Calendar of State Papers..., no 634). 
wrót na kontynent i ostatecznie - ponownie do Polski ${ }^{44}$. Ciekawe, że polski tłumacz, który nie mógł nie słyszeć o sprawie Bosgrave’a (do stycznia 1585 r. przebywającego w angielskim więzieniu), nie dodał $\mathrm{w}$ tym miejscu żadnych uzupełnień dotyczących młodego jezuity ${ }^{45}$. Niemniej jednak ten fragment relacji Personsa, jako zawierający jedyne bodaj polonicum, warto przytoczyć:

Pisze tedy eques Martius strażnikowi zamku swego, rozkazując, aby się pytał, jeśliby byli którzy papistowie w jego więzieniu, którzy by chcieli dysputując strony swojej bronić, żeby posłali spisane swoje artykuły, których bronić chca, żeby się przy tym podpisali i do potkania nagotowali, a iż on wrychle miał oznajmić o sposobie i czasie tego spirania. Podobało się to wszystkim. Trzej naszy kapłani, chocia młodszy i w naukach nie tak zastarzeli (bo powiedziałem wyższej, iż uczeńsze i ćwiczeńsze z Londynu wyprowadzono), podjęli się tego, ufając prawdzie swej, i podpisawszy a zapieczętowawszy artykuły swoje, z wielką dzięką posłali. One artykuły nie podobały się przeciwnikom i odmieniwszy, swoje, jakie się im podobały, odesłali naszym. Oni i na tych przestali. Naznaczony jest dzień do rozprawy, wiele ludzi zjeżdżało się do tego aktu. Cóż z tego? W ostatni dzień (zda mi się) przed dniem naznaczonym przerzeczeni obrońcy naszej strony z tego więzienia equitis Martii byli na zamek londyński

44 Szerzej o dramatycznej historii Bosgrave'a, tu wspomnianej w największym skrócie, por. P. Skwarczyński, Elsinore 1580: John Rogers and James Bosgrave, „Recusant History” 1982, 16, s. 1-16; T. M. McCooga SJ, „Godly Confessor of Christ”: The Mystery of James Bosgrave, w: Jezuicka ars historica. Prace ofiarowane ks. prof. Ludwikowi Grzebieniowi SJ, WAM - Ignatianum, Kraków 2001, s. 355-375. McCoog wiele uwagi poświęca przyczynom zawieszenia wyroku, dowodząc, iż przełożeni Bosgrave'a byli przekonani, że jego odpowiedzi na tzw. bloody questions $\mathrm{w}$ trakcie przesłuchania nie były w pełni zgodne z nauczaniem papieskim i stanowiskiem Towarzystwa. Claudio Aquaviva rozważał nawet relegowanie Bosgrave'a z zakonu, lecz wstawiał się za nim sam Persons. Streszczenie listu Batorego w sprawie Bosgrave'a zob. Calendar of State Papers, Foreign Series, of the Reign of Elizabeth, January-June 1583 and Addenda, ed. A. J. Butler, S. Crawford Lomas, London 1913, no 707).

45 Jak podaje P. Skwarczyński (Id., op. cit., s. 5, 12), w korespondencji denuncjatora Bosgrave'a istnieją poszlaki świadczące o tym, że mógł on nawet przez jakiś czas przebywać w Poznaniu jeszcze przed 1580 rokiem. $Z$ całą pewnością trafil do poznańskiego kolegium już po powrocie do Polski. Por. także: T. M. McCoog SJ, op. cit., s. 357. Zob. także list Johna Rogersa do Walsinghama z 10 X 1580 (Calendar of State Papers, Foreign Series, of the Reign of Elizabeth, January-June 1583 and Addenda, no 590). 
przeniesieni na próbę katowską; iż których rozumnymi dowody zwyciężyć nie możono, aby ich rozumem rozpalonego żelaznego konia przegadano. ${ }^{46}$

Marginalia informują o terminie dysputy — listopad 1580 r. — i podają nazwiska duchownych: James Bosgrave, Sherwin, Hart ${ }^{47}$. „Rozpalony żelazny koń” (w innych miejscach polskiej translacji „ognisty koń”, co wskazywać może na pewną dezorientację tłumacza, czy wreszcie po prostu „konik” ${ }^{48}$ to equleus, rodzaj madejowego łoża, szczególnie ważne $\mathrm{w}$ angielskich realiach narzędzie tortur, które narrator opisuje dopiero w ostatniej części relacji dającej już opis procesu, a później egzekucji Campiona i jego towarzyszy:

A ten konik jest jeden katowski warstat, na którym człowieka na wznak rościągnąwszy, powrozami od ostatnich członków aż do bliższych na prasach tak rościągają, aż wszystkie członki z stawów swych wyrwą. ${ }^{49}$

46 Okrucieństwo kacyrskie..., s. 109-110. Por. „Scribit itaque eques Martius sui castri custodi, mandatque ut disquirat, si qui sint suae custodiae subiecti papistae, qui velint disputando partes suas defendere, transmittant scripto conclusiones defendendas, adscribant nomina, parent se ad praelium, ipsum renuntiaturum statim de modo, de loco, de tempore certaminis. Res placuit universis. Tres nostri sacerdotes, aetate licet iuniores, et litterarum in studiis minus provecti (sic!) (robustiores enim et magis exercitatos omnes Londino dismissos dixi) accipiunt causae confidentia provinciam; obsignatas conclusiones, subsignatis nominibus, cum ingenti gratiarum actione transmittunt. Non placent adversariis conclusiones, statuuntur aliae pro illorum arbitrio; remittuntur, admittuntur a (Lib. nobis) nostris. Dies campi indicitur, excitatur ingens expectatio. Quid denique? Pridie, opinor, quam dies expectatus advenisset, defensores supradicti nostrarum partium, dimoventer hoc equitis Martii carcere et in arcem Londinesem transferuntur ad quaestionem, ut qui rationibus petitis ab auctoritate non flectebantur, argumentis ductis ab equuleo exercerentur [...]" (De persecutione Anglicana libellus..., s. 67-68).

${ }_{47}$ T. M. McCoog twierdzi, że Bosgrave był świadkiem dysputy Campiona, która miała miejsce 31 VIII 1581 r., lecz nie pozwolono mu wziąć w niej udziału (Id., op. cit., s. 368). Niedoszła debata opisywana w relacji Personsa zaplanowana była wcześniej, na 29 XII 1580 r. (ibidem, s. 367).

48 Okrucieństwo kacyrskie..., s. 67, 161.

49 Ibidem, s. 161-162. Por. „Id est tormenti genus, in quo supinum hominem primo extendunt, manusque ac pedes articulatim ligant, funes deinde, quibus ligatus est, rotis quibusdam paulatim eosque trahunt, donec omnia membra luxentur" (De persecutione Anglicana libellus..., s. 97). 
To w opisie procesu dwukrotnie jeszcze powróci - już w tekście głównym - nazwisko Bosgrave’a jako jednego z oskarżonych i torturowanych:

Bo roku 1581 dnia 20 listopada, którego świętego Edmunda króla angelskiego w Anglijej święca, pozwani są do sądu ci kapłani: Edmundus Campianus, Jacobus Bosgravius, Zebrania Pana Jezusowego zakonnicy [...] Campianum lepak, Serwinum, Briantum, Jansonium, Bosgravium i inszych jakmiarz do wytargania wszystkich członków, a mało nie do śmierci na koniku męczyli. ${ }^{50}$

I w tym kontekście jednak polski tłumacz nie wprowadza żadnej interpolacji czy komentarza dotyczącego uwięzionego wileńskiego profesora.

Uwolnienie udręczonego i schorowanego Bosgrave'a z Tower w r. 1585 zwykło się łączyć z interwencją Batorego u Elżbiety I. Jak zauważył jednak Paweł Skwarczyński, powody decyzji królowej mogły być bardziej złożone i związane także z negocjacjami, jakie jej rząd prowadził z Polską oraz z władzami Elbląga w sprawie dostępu kupców angielskich do handlu w tym bałtyckim porcie. Dyplomacja angielska zabiegała wówczas zarówno o przychylność polskiego króla, jak i elbląskich mieszczan ${ }^{51}$. Niezwykle interesujący wydaje się w tym kontekście cytowany przez Pawła Skwarczyńskiego list protestanckich członków rady miejskiej Elbląga, datowany na 31 marca 1583 r., a skierowany do królowej Anglii:

Ponadto chcielibyśmy powiadomić Waszą Królewską Mość, że nuncjusz papieski, który wiele znaczy na dworze naszego króla, rozpowszechnia listy o pewnych zakonnikach czy księżach z Towarzystwa Jezusowego, narzekając, że są najokrutniej więzieni w królestwie Waszej Królewskiej Mości, a z powodu swej religii dręczeni bolesnymi i ostrymi torturami. ${ }^{52}$

50 Ibidem, s. 160-161. Por. „Nam hoc ipso 1581 anno, die Novembris 20, qui D. Edmundo Angliae regi sacer est, et sequenti vocati sunt ad Tribunal hi sacerdotes: Edmundus Campianus, Iacobus Bosgravius, Societatis Iesu religiosi [...]. Campianum autem, Shervinum, Briantum, Iansonium, Bosgravium, et alios ad omnium membrorum usque divulsionem, et pene ad mortem ipsam equuleo torserant [...]" (De persecutione Anglicana libellus..., s. 96-97).

51 Por. P. Skwarczyński, op. cit., s. 10.

52 Ibidem, s. 11. Por. Calendar of State Papers, Foreign Series, of the Reign of Elizabeth, January-June 1583 and Addenda, no 723. Tłumaczenie z języka angielskiego pochodzi od autorki artykułu [M. H.-L.]. 
Następnie stwierdzają, że dołączają uzyskaną przez ich pośrednika kopię owego listu, aby poseł angielski mógł się przygotować do odparcia tych fałszywych - jak wierzą — zarzutów. W tym kontekście przypomnieć warto, że Okrucienstwo kacyrskie... ma właśnie formę listu, a wydane zostało zaledwie kilka miesięcy przed tym, jak elbląscy mieszczanie skierowali swoje pismo do królowej. Nie można wykluczyć, że mowa właśnie o tym dziełku (które mogło być przekazane Elżbiecie w wersji łacińskiej lub nawet angielskiej), a zaangażowanie nuncjusza (w r. 1583 był nim Alberto Bolognetti) w rozpowszechnianie relacji znanego i wpływowego Roberta Personsa również nie jest nieprawdopodobne.

Wieści o losach Bosgrave'a, które docierały do Polski już po procesie i egzekucji Campiona, musiały być bardzo skąpe lub zgoła żadne, skoro Skarga, opracowując kolejne wydanie Żywotów świętych w r. 1585, umieścił swego byłego podwładnego i „najmilszego brata” wśród męczenników angielskich, choć przyznać trzeba, że nie tylko nie informuje o jego egzekucji, ale nawet dodaje enigmatycznie, że „innych śmierć odwleczona była" ${ }^{53}$. Pierwszy list Batorego do Elżbiety w sprawie Bosgrave’a i innych więźniów datowany jest na 29 stycznia 1583 r.

53 Pisał Skarga: „Potępieni z nim są zaraz na takąż śmierć kapłani święci i barzo uczeni: Radulphus Servinus, Lucas Chirbeus, Iacobus Bosgravius, Cothamus i Iansonus, Alexander Briantus. Iacobus Bosgravius i Cothamus byli także ex Societate Iesu. Tego Bosgrawiusza jam z Wilna, będąc tam niegodnym starszym, gdzie on matematykę czytał i polskiego się języka, Anglikiem będąc, dobrze nauczył, na to męczeństwo z rozkazania Księdza Generała wyprawował. Pomnię cię, namilszy bracie, gdyś u mnie opończej na tę drogę, którąm był ze Włoch przyniósł, prosił, i gdym cię w nię ubierał, a Chrystus cię świadkiem swoim obierał i na takie męczeństwo uzbrajał" (Id., op. cit., s. 1130). Skorygował to wszakże w kolejnych wydaniach, pisząc: „Potępieni z nim [tzn. z Edmundem Campionem; M. H.-L.] są zaraz na takąż śmierć kapłani święci i barzo uczeni: Radulphus Servinus, Lucas Chirbeus, Jacobus Bosgravius, Cothamus i Jansonus. Aleksander Brianthus, Jacobus Bosgravius i Cothamus byli także ex Societate Jesu. Tego Bosgraviusa jam z Wilna, będąc tam niegodnym starszym, gdzie on matematykę czytał i polskiego się języka, Anglikiem będęc, nauczył, na to męczeństwo z rozkazania Księdza naszego Generała wyprawował. Innych śmierć odwleczona była i za czasem Bosgraviusa, za niejakim listem króla Stefana do królowej angielskiej, w którym jej katoliki i tego Bosgraviusa jako swojego zalecał, wybawiony był" (Żywoty swiętych Starego i Nowego Zakonu, Kraków 1601, w druk. A. Piotrkowczyka, s. 1163, egz. Boss XVII 15595). Usunięcie serdecznego wspomnienia o użyczonej bratu opończy zdaje się świadczyć o subtelnej zmianie stosunku do Bosgrave’a, który z niejasnych przecież powodów śmierci męczeńskiej jednak uniknął. W roku 1585 Skarga zdaje się o tym jeszcze nie wiedzieć. 
Czy dotarły do Skargi wieści z królewskiego dworu dotyczące uwięzionego współbrata? ${ }^{54}$ Możliwe, że i w tym wypadku De persecutione anglicana Personsa, która, przedstawiając Bosgrave'a jako torturowanego i współoskarżonego w procesie Campiona, bynajmniej nie dawała żadnych informacji o tym, co stało się później, skłoniła do przypuszczeń, iż ostatecznie młodego jezuitę spotkała śmierć męczeńska. Warto zapewne zbadać, czy Przydatek [...] o świętych męczennikach, którzy tych naszych wieków [...] cierpieli w wydaniu z r. 1585 nie zawiera odniesień do relacji Personsa, obok rozpoznanych już innych źródeł, czyli przede wszystkim Wawrzyńca Suriusa, Mikołaja Sandersa, Emmanuela Acosty i Alana Copusa 55 .

Spór o prawdziwych i fałszywych męczenników, znany ze starożytności chrześcijańskiej, lecz odnowiony w Europie w dobie reformacji, w Polsce miał swoją pierwszą odsłonę w latach sześćdziesiątych i siedemdziesiątych dzięki publikacji — z jednej strony — obszernego martyrologium Cypriana Bazylika, z drugiej zaś - właśnie Żywotów swiętych, w których pojawił się wspomniany już „przydatek”. Dziełko De persecutione Anglicana... zostało bezbłędnie zinterpretowane przez polskiego tłumacza i wydawcę właśnie jako bardzo cenny głos w tym sporze. Choć nazwisko angielskiego autora nie pojawiło się na karcie tytułowej (nie było go także w wydaniach łacińskich i translacjach na inne języki narodowe), można sądzić, że w środowisku jezuickim atrybucja oryginału nie była sekretem, Persons bowiem był osobistością bardzo znaną (wspomina go także jako „ojca Personiusza” Skarga w Żywotach swiętych $)^{56}$. Unikalna rama wydawnicza wprowadza w istocie historyczną relację Parsonsa w kontekst teologiczny, eksponuje, z odwołaniem się do autorytetu Ojców, kryterium prawdziwego męczeństwa, którym jest przede wszystkim jedność z Kościołem, będąca podstawowym try-

54 Zachował się skierowany do Skargi list kaznodziei królewskiego Marcina Laterny SJ (z 1 VIII 1581) zawierający wzmiankę o próbach nakłonienia króla do interwencji w sprawie uwięzionych w Anglii jezuitów. Jednym z nich był wówczas Bosgrave, choć w więzieniu pozostawał także jeszcze Campion (zob. Listy Ks. Piotra Skargi z lat 1566-1610, wyd. J. Sygański TJ, Kraków 1912, s. 155).

55 W kolejnych wydaniach, w których „przydatek” był odpowiednio rozwijany, Skarga korzystał też z nowych źródeł, w tym m.in. ze wspomnianego wcześniej dzieła Johna Bridgewatera. Na ten temat zob. A. Ceccherelli, Od Suriusa do Skargi. Studium porównawcze o „Żywotach świętych”, Świat Literacki, Izabelin 2003, s. 101-105.

56 Por. P. Skarga, Żywoty świętych, Kraków 1585, s. 1132. 
bem trwania w miłości Chrystusa. W zamykającym książkę przekładzie dzieła św. Cypriana wybrzmiewa bardzo silnie ta zasada:

Nie może być męczennikiem, kto w Kościele nie jest, do królestwa wiecznego przyść nie będzie mógt, kto tego Kościoła, który królować ma (to jest widomego, powszechnego), odbiega. Pokój nam Krystus zostawił, zgodnymi i jednomyślnymi być rozkazał, życzliwości a miłości związki stateczne i nienaruszone chować rozkazał. Otóż nie może się udać za męczennika, kto miłości brackiej nie zachował. Naucza tego i poświadcza Paweł Apostoł, mówiąc: „Bych miał wszytkę wiarę, tak iżbych góry przenosił, a nie miałbych miłości, za nic nie stoję. [...] Kto miłość Krystusowę zdradzieckim rozterkiem zgwałcił, ten nie może przyść do zapłaty Jego, który powiedział: „To jest rozkazanie moje, abyście się spólnie miłowali, jakom ja was umiłował". Kto miłości nie ma, ten Boga nie ma. Jana św. Apostoła głos jest: „Bóg” — mówi — „miłością jest. Otóż kto mieszka w miłości, w Bogu mieszka, a Bóg mieszka w nim”. A z Bogiem nie mogą-ć mieszkać, którzy w Kościele Jego jednostajnie trwać nie chcieli. By też od płomienia gorzeli i w ogień wrzuceni abo bestyjam na rozdrapanie zdrowie swoje odważyli, tedy to nie będzie korona abo zapłata wiary, ale karanie złamania jej. Ani to będzie poczciwe dla pobożnej cnoty żywota dokończenie, ale marne a desperackie zginienie. Zabitym taki być może, ale koronowanym być nie może. ${ }^{57}$

Trwanie w jedności z Kościołem okazuje się podstawowym kryterium prawdziwego męczeństwa. Ci zatem, o których mowa w Okrucieństwie..., okazują się — w świetle teologii patrystycznej — „ukoronowanymi” świętymi Chrystusa. A przecież narrator-świadek w swojej relacji przywołuje także kryteria pozadoktrynalne, takie jak podziwu godna stałość, pokora i cierpliwość męczenników, potęga ich świadectwa, przez które pozyskują nowych wyznawców, cuda, a nawet (podkreślany przez Personsa) ich wysoki stan społeczny i wykształcenie ${ }^{58}$. Wprowadzenie do ramy wydawniczej dzieła fragmentu przekładu traktatu św. Cypriana nadaje przejmującemu przecież historycznemu świadectwu angielskiego jezuity funkcję argumentu w kontrowersji, bardzo podobnego do tego, jakim posłużył się Skarga we wspominanym tu już kilkakrotnie Przydatku... Nie koniec jednak na tym. Bo przecież ci, którzy „popędliwością niezgody swej” rozrywają Kościół, a męczennikami i tak stać się nie mogą, w pełni zasługują

57 Okrucieństwo kacyrskie..., s. 186-189.

58 Por. B. Gregory, op. cit., s. 323-328. 
na to, by wszelkimi sposobami ich powstrzymać. Obraz męczenników prawdziwych, czyli katolickich, nadto opatrzony stosownym komentarzem teologicznym i wzmocniony autorytetem św. św. Augustyna i Cypriana, służy więc - w polskiej wersji dzieła - nie tylko umocnieniu przywiązania do Kościoła i przestrodze przed prześladowaniami katolików, do jakich niechybnie dojdzie, jeśli się nie zapobiegnie temu, „by kacyrstwa góry a regimentu w Polszcze nie brały"59, ale także jest formą obrony przed zarzutami o fizyczne prześladowanie innowierców:

Przetoż Kościół prześladuje ich z miłości, on<i> zasię Kościół — z nienawiści, $<$ on> dla ich polepszenia — oni dla jego wywrócenia, on dla z błędu wyważenia — oni lepak dla błędem swym zarażenia, na koniec Kościół strofuje ich ku dostąpieniu dobra wiecznego, oni przeciw temu Kościół prześladują i pozbawiają dobra doczesnego. ${ }^{60}$

Paraleli zatem nie ma, między męczeństwem a uzasadnionym strofowaniem zachodzi poważna różnica teologiczna, mimo zewnętrznych egzystencjalnych podobieństw - to może najważniejszy przekaz polskiej wersji $D e$ persecutione Anglicana... Paradoksalną, doprawdy, funkcję tej przejmującej narracji o prześladowaniu katolików zaprojektował nasz tłumacz.

\section{Okrucieństwo kacyrskie przeciw katolikom w Anglijej. A Polish Voice in the Debate about Martyrdom}

This article analyzes the book Okrucieństwo kacyrskie przeciw katolikom w Anglijej, krótko a prawdziwie przez jednego tegoż narodu opisane, a na polski jezzyk przetożone (Poznań 1582), and recognizes it as a hitherto unidentified Polish translation of the epistle De persecutione Anglicana by the English Jesuit Robert Persons (vel Parsons). Okrucienstwo kacyrskie was probably based on one of the Latin editions of Persons' text (1582), containing its second version, different from the first, which had been used for the English translation. The Polish translator remains anonymous, though there are certain premises favouring attribution to Hieronim Powodowski. The book opens with the original long preface, where reference to St Augustine's principle martyrem facit non poena,

59 Okrucieństwo kacyrskie..., k. D4r.

60 Ibidem, k. A6v. 
sed causa makes the author not only condemn persecutions of the Catholics in England, but also warns against the heretics gaining political power in the Commonwealth and, paradoxically, justifies using religious coercion against them. Persons' text was rendered faithfully, without any significant reductions or amplifications, and is followed by the unique Polish translation of the 8th chapter of St Cyprian's De Ecclesiae catholicae unitate, dealing with the problem of true martyrdom. By adding these elements, the Polish author moved Persons' epistle on to a more general level and transformed it into an argument in the then current debate on true and false martyrs. 